\title{
К ВОПРОСУ О РАЗВИТИИ ЛИДЕРСТВА У ДЕТЕЙ В СТАРШЕМ ДОШКОЛЬНОМ ВОЗРАСТЕ
}

\section{TO THE ISSUE OF LEADERSHIP DEVELOPMENT FOR CHILDREN IN OLDER PRESCHOOL YEARS}

\section{T. Savenkova \\ S. Karpova}

Summary: The article substantiates the necessity of purposeful pedagogical work on leadership development in children in the senior preschool age. On the basis of the analysis of domestic and foreign sources, the authors have defined structural and substantial characteristics of leadership abilities in older preschool children and developed a program for their development in the conditions of preschool educational organization. A distinctive feature of the programme ("Everyone can become a leader») is its focus on enabling every child in preschool groups to become an organizer and leader of various types of joint activity with his or her peers, and not only those children who have a sufficient level of leadership development as a result of diagnostics, or who clearly demonstrate them. Necessary conditions for the successful implementation of the program for the development of leadership skills in older preschool children are: methodological support of preschool teachers to improve their professional skills in the field of manifestation and development of leadership in older preschool age and building a system of cooperation between teachers and families of students at the level of socio-pedagogical partnership.

Keywords: children's leadership, older preschool children, leadership development program.

\author{
Савенкова Татьяна Дмитриевна \\ к.п.н., дочент, ГАОУ ВО «Московский городской \\ педагогический университет» \\ tdpichik1@yandex.ru \\ Карпова Светлана Ивановна \\ д.n.н., профессор, ГАОУ ВО «Московский городской \\ педагогический университет» \\ karpova_svetlana@inbox.ru
}

Аннотация: В статье обосновывается необходимость целенаправленной педагогической работы по развитию лидерства у детей в старшем дошкольном возрасте. На основе анализа отечественных и зарубежных исследований авторы определили структурно-содержательные характеристики лидерских способностей у детей старшего дошкольного возраста и разработали программу их развития в условиях дошкольной образовательной организации. Отличительной особенностью программы («Каждый может стать лидером») является ее направленность на предоставление возможности каждому ребенку в дошкольных группах стать организатором и руководителем различных видов совместной деятельности со сверстниками, а не только тем детям, у которых в результате диагностики выявлен достаточный уровень развитости лидерских качеств, или которые ярко их проявляют. Необходимыми условиями успешной реализации программы развития у старших дошкольников лидерских способностей являются: методическое сопровождение педагогов дошкольной организации с целью совершенствования их профессиональных компетенций в области проявления и развития лидерства в старшем дошкольном возрасте и выстраивание системы сотрудничества педагогов с семьями воспитанников на уровне социально-педагогического партнерства.

Ключевые слова: детское лидерство, дети старшего дошкольного возраста, программа развития лидерских способностей.

ечественными (М.А. Викулина, М.Н. Емельянова, Т.В. Каширских, В.С. Мухина, Т.А. Репина, А.И. Савенков и др.) и зарубежными (M. Sun Shin, D. Sisk, H. Rosselli, R.Yamaguchi и др.) учеными определяется как сензитивный для развития лидерских качеств (высокая восприимчивость к социальным воздействиям, развитие элементов произвольности, самоконтроля, самооценки и др.); а дошкольная группа - как первая социальная группа, в которой находятся истоки феномена лидерства [16]. Практика показывает, что в каждой группе дошкольников есть дети - вожаки, личностные качества которых позволяют им быть неформальными лидерами среди сверстников: выполнять ведущие роли в играх, руководить деятельностью детей, влиять на их поведение и т.д. Стремление к доминированию ребенка-лидера в группе сверстников имеет как положительную направленность (доброжелательность, готовность помочь, поддержать), так и отрицательную (демонстрация превосходства, агрессивность, желание подчинить себе других детей). При- 
чем, отрицательный характер доминирования нередко встречается на практике, когда сила влияния ребенкалидера такова, что многие дети не могут противостоять ей и стремятся достичь дружеских взаимоотношений с лидером, для чего вынуждены занимать подчиненное, зависимое положение, лидеру уступают, соглашаются с его мнением, снисходительно относятся к проявлению грубости, к ошибкам и т.д. Такие отношения между детьми могут иметь скрытый характер и не проявляться до определенного времени, пока не произойдет конфликтная ситуация и воспитатель не обратит на это внимание. Отсутствие программы специальной педагогической работы по формированию у дошкольников представлений о сущности лидерства и качествах настоящего лидера, созданию условий для выявления у каждого ребенка лидерского потенциала и развития лидерских способностей негативно сказывается на межличностных отношениях детей в группе, препятствует воспитанию у них социально-ценных навыков поведения. В итоге на практике лидерство как социально-психологический процесс в дошкольных группах развивается стихийно, а сензитивный период старшего дошкольного возраста не используется для развития положительных лидерских качеств у детей (целеустремленности, ответственности, доброжелательности, самостоятельности и др.).

Историко-педагогический анализ проблемы детского лидерства показал, что первые попытки исследования данного феномена были предприняты отечественными и зарубежными учеными в начале XX века (D.M. Baldunin, A. Beaver, В.П. Вахтерев, В. Winifred, J. Warendonck, W. Doering, А.Ф. Лазурский, Г.А. Фортунатов и др.). Изучались детские группы (организованные и стихийные) и личности лидеров в этих группах, отмечалось, что возглавляют детские объединения аффективно-деятельные дети (А.Ф. Лазурский), смелые и ловкие, с острым умом, с умениями хорошо планировать и предугадывать желания других членов группы. Было выявлено, что главарями детских группировок с довольно сложной организацией становились дети в возрасте 6-8 лет - «сильные личности с большой инициативой» (J. Warendonck) [2,c.36].

В 1920-30-е годы в связи с программой по борьбе с беспризорностью в стране отечественными ученымипедологами (Е.А. Аркин, П.П. Блонский, А.Б. Залкинд, В.С. Красуский, С.О. Лозинский, И.В. Эвергетов и др.) изучались социальные и биологические корни детского лидерства (детвожачества), типы вожаков, их гендерные особенности, характер взаимодействий с коллективом, в том числе «в области яслевого и дошкольного возраста» (А.Б. Залкинд) [3, с.299]. В итоге были получены ценные данные и сделаны выводы о том, что лидер представляет собой «квинтэссенцию характерных качеств коллектива... Он обладает теми качествами, которые для данного коллектива являются идеальными» (П.П. Блонский) [1,с.484]. А само явление детского «вожачества» имеет динамичный характер, выполняя роль вожака в одном коллективе, тот же самый ребенок делается нередко пассивным членом другого коллектива, в зависимости от возрастных и индивидуальных особенностей детей, входящих в состав детского объединения, а также от жизненного опыта в том или другом виде деятельности [3]. Поэтому проблема детского лидерства рассматривалась отечественными учеными с позиции изучения детского коллектива и личности в группе. После 1936 года исследования прекратились и до 1990-х годов детское лидерство не являлись предметом специальных научных исследований. Отдельные аспекты проявления лидерства у дошкольников были выявлены учеными в ходе изучения других проблем (взаимоотношений детей в коллективе, организации игровой и других видов деятельности). Так, в процессе исследования взаимоотношений дошкольников и формирования у них организаторских умений отмечалось, что уже в 2,5-3 года проявляются разные типы детей - организаторов, оказывающих влияние на других детей: у некоторых из них на первый план выступают эмоционально-волевые качества, у других логическая рассудительность при оценке ситуации (Е.И. Кульчицкая -1964; А.И. Матусик - 1966). От организаторских способностей лидера и его личностных качеств зависит стабильность и длительность игровых объединений (Р.А. Иванкова - 1978). Отношения лидерства и подчинения у старших дошкольников носят устойчивый и дифференцированный характер; от особенностей поведения лидеров в значительной мере зависит характер взаимоотношений между детьми в группе (Л.В. Артемова - 1970; В.С. Мухина -1980; Т.А. Репина - 1984; А.А. Рояк 1988; Р.Б. Стеркина - 1990). В старшем дошкольном возрасте у детей отчетливо проявляются авторитарный и демократический типы лидеров (В.Ф. Ануфриева -1973). Высокий статус и ярко выраженные организаторские способности характерны для дошкольников с преобладанием в поведении положительных форм доминирования (Р.А. Максимова - 1970; Т.В. Сенько - 1985; Т.Д. Марциновская - 1987). В работах Л.И. Уманского (1964), Щедровицкого (1973), Л.П. Бухтияровой, Т.А. Репиной (1978), В.В. Абраменковой (1981), О.М. Гостюхиной (1984), М.А. Викулиной (1997), М.Н. Емельяновой (2003) отмечается, что лидерство у дошкольников возникает в условиях организации детьми разных видов совместной деятельности. Организаторская деятельность дошкольников носит всегда включенный характер (организатор является и исполнителем). Необходимым условием для проявления ребенком лидерских качеств и становления лидерства среди сверстников является достижение успеха в совместной с ними деятельности.

Анализ зарубежных исследований свидетельствует о неослабевающем научном интересе к изучению феномена детского лидерства, начиная с XX века. В публикациях разных лет проходит информация о том, что лидерские качества у детей отчетливо проявляются уже 
в раннем возрасте и таких детей можно считать одаренными (C. Bühler - 1931; F. Montgomery - 1948; M.E. Bonney, J. Powell - 1953; L. Addison - 1985; N. Hensel - 1991; D. Sisk, H. Rosselli - 1996; R.Yamaguchi - 2003; D. L Fox, L. Flynn, P. Austin - 2015; J Billsberry, E.Vega, J. Molineu - 2019 и др.). Отмечается, что даже в детском саду есть дети, которые владеют собственной эффективной концепцией лидерского поведения (D. Haan - 1962; S. Fukada, H. Fukada, J Hicks - 1994; J Billsberry, E.Vega, J. Molineux - 2019) [9]. Ученые акцентируют внимание на необходимости всестороннего изучения феномена детского лидерства (структура, поведенческие характеристики, характер доминирования, взаимодействия со средой и др.). Разработаны графики наблюдений и рейтинговые шкалы (V. Fu- 1970; T. Harms, R. M. Clifford, D. Cryer - 2012 и др.); инструменты для измерений лидерских проявлений (Е. Shaunessy, F. Karnes - 2004 и др.); рекомендации для учителей по поддержке детей-лидеров (N.H. Hensel - 1991; L. Roets - 2000; S. Scheer, R. Safrit - 2001; D. L Fox, L. Flynn, P. Austin - 2015 и др.). Подчеркивается необходимость обучения лидерскому поведению детей, начиная с раннего возраста, предлагается использовать ролевые игры и драматизации, учебное сотрудничество в малых группах [10;11]. Внимание учителей обращается на возможное проблемное поведение маленьких детей - лидеров (шум, нарушение правил поведения) и дается совет не препятствовать проявлять лидерам свои качества, а всячески поддерживать их и развивать [8;13]. В программах обучения детей лидерству акцентируется внимание на воспитании у лидеров честности, великодушия, ответственности, открытости, креативности, навыков гибкого социального поведения («soft-skills» - регулирование своего поведения в соответствии с ситуацией, способность разрешать конфликты), навыков сотрудничества через доверие $[4 ; 9 ; 12 ; 14]$. В современных зарубежных публикациях отмечается, что, несмотря на множество научных работ по проблеме лидерства, данная проблема не изучена, особенно в области детского и подросткового возраста. Чтобы иметь наиболее полные представления о лидерстве, необходимо выстраивать длительные исследования, позволяющие проследить развитие детей, проявивших лидерские качества в раннем детстве, на всех последующих этапах жизни (периоды обучения, на рабочем месте в зрелом возрасте) $[9 ; 10 ; 15]$.

Анализ отечественных и зарубежных исследований по проблеме проявления и развития лидерства в дошкольном возрасте позволил сделать следующие выводы:

- лидерство в старшем дошкольном возрасте рассматривается как процесс активного влияния (как положительного, так и негативного) ребенка-лидера на группу сверстников;

- к «эталонному набору» лидерских качеств ребенка старшего дошкольного возраста ученые относят: инициативу, коммуникативные умения, творческое мышление, речевую активность, навыки гибкого социального поведения (soft-skills), исполнительность, самостоятельность, эмпатию, адекватную самооценку, владение навыками продуктивной деятельности;

- лидерство у дошкольников возникает на реальной почве организаторской активности в различных сферах групповой жизнедеятельности;

- необходимым условием для проявления ребенком лидерских качеств и становления лидерства среди сверстников является достижение успеха в совместной с ними деятельности.

С учетом выделенного большинством ученых перечня лидерских качеств мы определили структурные компоненты лидерских способностей старших дошкольников: когнитивный (знания, творческое мышление, речь); мотивационный (желание занять приоритетное место в межличностных отношениях, участвовать в совместной деятельности со сверстниками, организовывать и руководить совместной деятельностью); перцептивный (эмпатия, готовность оказать помощь, поддержать), операциональный (коммуникативные, организаторские, продуктивные умения и навыки), рефлексивный (адекватная оценка себя, сверстников и результата совместной деятельности).

Результаты теоретического анализа научных работ по проблеме детского лидерства, а также собственный опыт проведения исследования по проблеме развития у старших дошкольников социального интеллекта в совместной деятельности позволили разработать программу развития лидерских способностей у старших дошкольников «Каждый может стать лидером!». Программа включает три образовательных блока, в каждом блоке программы акцентируется внимание на развитии определенных компонентов лидерских способностей.

В первом блоке («Что такое лидерство и каким должен быть лидер») происходит активное развитие когнитивного и рефлексивного компонентов лидерских способностей. У ребенка формируются знания и представления о значении понятия «лидерство», о качествах личности настоящего лидера, представления о себе, своих личностных качествах, о себе как о члене группы. Детям предлагается составить рассказы: о себе «Визитная карточка», о себе как о члене группы «Я и моя команда», «Умеем ли мы дружить», «Как можно избежать ссоры» и др. В процессе составления рассказов и беседы с педагогом у ребенка формируется рефлексивная позиция (А.И. Уманский). В соответствии со стратегией обогащения содержания образования для развития творческого мышления, умений выявлять противоречия, находить несколько решений выхода из проблемных ситуаций, целесообразно использовать задания ТРИЗ (теория ре- 
шения изобретательских задач) [6].

Второй блок программы («Учимся понимать друг друга и общаться») направлен на развитие эмоциональной сферы, речевой активности, преодоление барьеров в общении, формирование коммуникативных умений. Внимание уделяется ознакомлению детей с образцами адекватного выражения своего эмоционального состояния, добрых чувств или, наоборот, негативных переживаний; дети знакомятся со способами реагирования на различные эмоции близких людей или сверстников (например, реакция на гнев, на обиду, на отвращение), приобретают опыт регулирования своего поведения в соответствии с коммуникативной ситуацией, в том числе, средствами детской субкультуры (считалки, «мирилки», ответ на «обзывалки» и др.). Можно использовать дидактические материалы, разработанные Г.Б. Мониной и Е.К. Лютовой - Робертс: «Как я решаю свои проблемы», «Как я справляюсь со своей тревогой», «Как я решаю конфликты», «Как я справляюсь со свои гневом». Это - плакаты и карточки, на которых изображены различные ситуации, характерные для дошкольников и младших школьников, а также варианты поведения в тех или иных ситуациях [5]. В процессе занятий по второму блоку программы активно развиваются перцептивный и мотивационный компоненты лидерских способностей. Работа с детьми по первым двум блокам программы является основой для перехода к третьему блоку «Учимся организовывать и руководить», в процессе которого акцентируется внимание на развитие операционального компонента лидерских способностей. Здесь каждому ребенку предоставляется возможность взять на себя функции лидера, стать организатором и руководителем разными видами совместной деятельности со сверстниками. Педагог в процессе руководства придерживается следующих правил: предоставлять роль организатора и руководителя разными видами совместной деятельности каждому ребенку при условии, что у него сформирован должный уровень компетенций для достижения с небольшой поддержкой педагога успешного результата; комплектовать группы детей для совместной деятельности на основе желания и готовности каждого ребенка к сотрудничеству; создавать ситуации, когда ребенку (организатору и руководителю) необходимо самостоятельно искать и обосновывать собственную стратегию деятельности, проявлять способность принимать решения. Переживание ситуации успеха повышает у ребенка уверенность в себе, порождает чувство компетентности, способствует становлению его лидерской позиции в группе сверстников. Задачи первых двух блоков программы реализуются на специальных занятиях; задачи третьего блока - в процессе разных видов совместной деятельности детей (игровой, трудовой, продуктивной и др.).

Отличительной особенностью программы является ее направленность на предоставление возможности каждому ребенку в дошкольных группах стать организатором и руководителем разных видов совместной деятельности со сверстниками, а не только тем детям, у которых в результате диагностики выявлен достаточный уровень развитости лидерских качеств, или которые ярко их проявляют. Достижению данной цели способствует заложенная в программе логика образовательного процесса, предусматривающая на занятиях по первым двум блокам программы развитие у детей должного уровня компетенций, необходимых для успешного выполнения самостоятельно, или с небольшой поддержкой педагога функций организатора и руководителя группой сверстников в каком-либо виде совместной деятельности (игровой, трудовой, художественной и др.). Выбор вида деятельности зависит от желания ребенка и от уровня сформированности у него продуктивных умений и навыков в выбранном виде деятельности.

Важнейшими условиями успешной реализации программы развития у старших дошкольников лидерских способностей являются: методическое сопровождение педагогов дошкольной организации с целью совершенствования их профессиональных компетенций в области проявления и развития лидерства в старшем дошкольном возрасте и выстраивание системы сотрудничества педагогов с семьями воспитанников.

С воспитателями целесообразно провести обучающие семинары, где обсудить содержание программы по развитию лидерских способностей у детей, методы и приемы руководства разными видами совместной деятельности детей, режим проведения занятий и дидактический материал, вопросы взаимодействия с семьями воспитанников. Основная цель работы с воспитателями заключается в том, чтобы они осознали важность задачи развития лидерских способностей у всех детей в группе, так как у каждого ребенка есть лидерский потенциал и он может проявить его в наиболее интересном и любимом виде деятельности, в котором у него сформированы необходимые умения и навыки. Следует предоставить ребенку возможность взять на себя функции организатора и руководителя совместной деятельностью с ответственностью за общий результат.

Систему сотрудничества педагогов с семьями воспитанников следует выстраивать на уровне социально-педагогического партнерства. Эта форма взаимодействия характеризуется единством взглядов на цели и задачи воспитательно-образовательной работы, добровольным сотрудничеством, объединением усилий партнеров для достижения поставленной цели, одобрением и использованием обеими сторонами общих педагогических стратегий. Чтобы родители включились в процесс воспитания лидерских качеств у детей, необходимо сформировать у них педагогически правильные представления о лидерстве, его проявлении и условиях раз- 
вития в детском возрасте, рассказать о программе, предложить участвовать в ней. В процессе реализации задач третьего блока программы («Учимся организовывать и руководить») предусматриваются совместные с родителями (членами семьи) мероприятия досугового характера, в ходе проведения которых разным детям делегируются функции организатора и руководства совместной деятельностью. Например, художественные мастерские по изготовлению новогодних игрушек; в ходе проведения мероприятия группа детей вместе с родителями делится на небольшие подгруппы для изготовления новогоднего украшения. Руководство каждой подгруппой предоставляется детям, которые наиболее компетентны в данном виде деятельности, они распределяют участников на каждый этап работы, объясняют, что и как надо сделать, участвуют сами и презентуют общий результат. Сейчас много вариативных форм взаимодействия с родителями (конференции, круглый стол, мастер-классы, педагогическая гостиная и др.), стимулирующих родителей высказать свои взгляды на многие волнующие педагогические проблемы и обсудить их с другими участниками, а педагогам ненавязчиво вовлечь родителей в образовательный процесс. В аспекте проблемы развития лидерства у старших дошкольников важно не только дать информацию по лидерству в целом, но и раскрыть перед родителями возможности развития лидерского потенциала у детей в условиях семьи. Например, предоставлять возможность ребенку организовать общие дела дома с участием других членов семьи, учить ребенка планировать последовательность действий, участвовать самому и нести ответственность за результат. Также можно предложить родителям проектировать в условиях семейного воспитания ситуации, способствующие проявлению и развитию у детей лидерских качеств (творческое мышление, самостоятельность, умение принимать решение, обосновывать свою позицию и др.).

Задача развития у детей старшего дошкольного возраста лидерских способностей не включена в перечень образовательных задач, представленных в Федеральном государственном образовательном стандарте дошкольного образования и примерных программах дошкольного образования; в отечественных дошкольных учреждениях отсутствует практика реализации программ развития лидерства у детей. В результате сложившейся ситуации не накапливается и не изучается эмпирический материал, стимулирующий к выдвижению гипотез и проведению исследований, разработке эффективных методик и образовательных программ, направленных на развитие лидерского потенциала дошкольников.

Мы считаем, что особое внимание в процессе развития лидерства следует уделять развитию у детей эмоционально-чувственной сферы и социального интеллекта, который у старших дошкольников проявляется в способности понимать эмоциональные состояния, мотивы своих поступков и поступков других людей; выделять существенные характеристики ситуации взаимодействия; находить способы выхода из конфликта; выбирать стратегии социального поведения и уметь применять их в различных ситуациях [7].

Программы по развитию лидерства в старшем дошкольном возрасте имеют большую педагогическую ценность: у детей формируется правильные представление о понятии «лидерство» и личности настоящего лидера, а также такие ценные качества, как: самостоятельность, ответственность, готовность принимать решения, навыки сотрудничества, дети становятся способными противостоять негативному влиянию ребенка - вожака в группе.

Перспективным направлением может стать разработка целостной программы развития лидерских способностей у детей на всех ступенях общего образования и включение данной программы в основную образовательную программу школы в качестве образовательного модуля с отдельными дисциплинами и видами деятельности.

\section{ЛИТЕРАТУРА}

1. Блонский П.П. Избранные педагогические произведения. М.: Изд-во Акад. пед. наук РСФСР, 1961.695 с.

2. Варендонк Ж. Детские сообщества. М.: Работник просвещения, 1926. 88с.

3. Залкинд А.Б. Основы пятилетнего плана по научно-исследовательской педологической работе// Педология. 1930. Вып. 3. №5. С.273-305.

4. Колосков И.А. Обучение лидерству в общеобразовательных школах (ША (на примере штата Вирджиния) //Вестник РМТ. 2019. №1. С. 104-111.

5. Монина Г.Б., Лютова-Робертс Е.К. Коммуникативный тренинг (педагоги, психологи, родители). - СПб.: Издательство «Речь», 2007. 224 с.

6. Савенков А.И., Карпова С.И., Вершинина Н.А. Обогащение содержания образования как фактор развития детской одаренности// Вестник Московского городского педагогического университета. Серия: Педагогика и психология. 2012. № 3 (21). С. 73-83.

7. Савенкова Т.Д. Развитие социального интеллекта дошкольников: учебное пособие для вузов /Т.Д. Савенкова. — Москва: Издательство Юрайт, 2020. 146 с.

8. Austin P. Child Leadership: Teachers' Perceptions and Influences. Journal Childhood Education. 2015. Vol. 91. № 3. P. 163-168.

9. Billsberry J., Vega E., Molineu J. Think of the children: Leader development at the edge of tomorrow. Journal Management \& Organization. 2019. Vol. 25. No 3. P. 378-381.

10. Bailey D., Hufford M., Emmerson M., Eckert S. Identifying and Living Leadership in the Lives of Prekindergarten Through 4th-Grade Girls: The Story of One 
Intentional Leadership Identity Development Program. Journal of Research in Childhood Education. 2017. Vol. 31. P. 487-507.

11. Certo J. L. Social Skills and Leadership Abilities Among Children in Small-Group Literature Discussions. Journal of Research in Childhood Education. 2011. Vol 25. No 1. P. 62-81.

12. Cerrato M.A., Thornton K., Haggerty M. Teachers' beliefs and practices regarding young children's leadership: A comparison between New Zealand and Honduras. Journal of educational leadership, policy and practice. 2019. Vol 33. P. 57-69.

13. Fox D.L., Flynn L., Austin P. Child Leadership: Teachers' Perceptions and Influences, Childhood Education, 2015. Vol 91. No 3. P. 163-168.

14. Hensel N.H. Social leadership skills in young children. Roeper Review. 1991. Vol. 14. No 1. P. 4-6.

15. Karagianni D., Montgomery L. Developing leadership skills among adolescents and young adults: a review of leadership programmes. International Journal of Adolescence and Youth. 2018. Vol 23. No 1. P. 86-98.

16. Vugt V.M., Rueden C.R. From genes to minds to cultures: Evolutionary approaches to leadership», Leadership Quarterly, 2020. Vol 31. No 2. P. 1-9.

○ Савенкова Татьяна Дмитриевна (tdpichik1@yandex.ru), Карпова Светлана Ивановна (karpova_svetlana@inbox.ru).

Журнал «Современная наука: актуальные проблемы теории и практики»
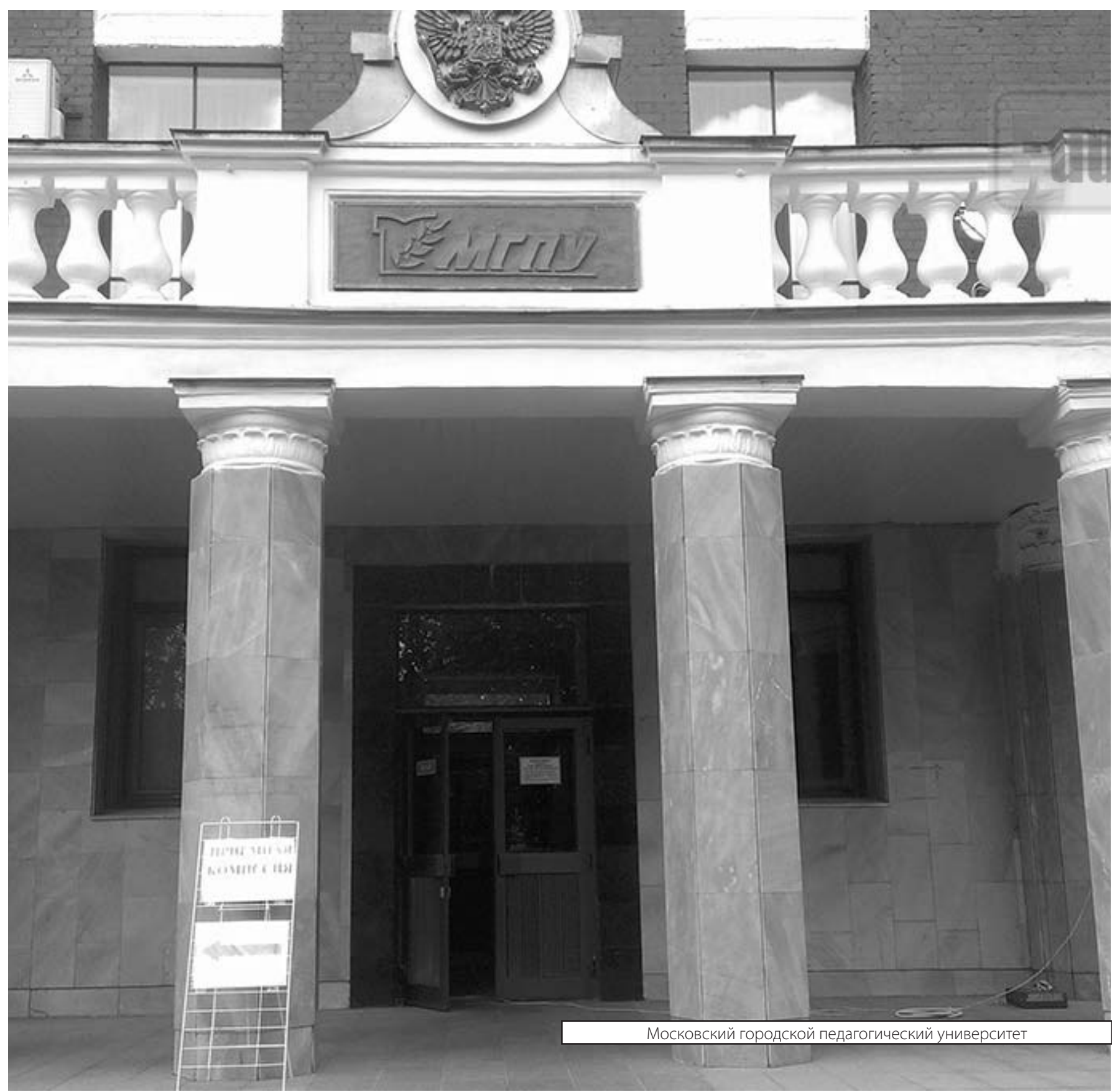